\title{
LC/MS/MS による畜水産食品中の動物用医薬品一斉分析
}

(平成 20 年 5 月 13 日受理)

\author{
梶田弘子*＼cjkstart畠山えり子
}

Simultaneous Determination of Residual Veterinary Drugs in Livestock Products and Fish by Liquid Chromatography with Tandem Mass Spectrometry

\author{
Hiroko Kajita* and Eriko Hatakeyama
}

Research Institute for Environmental Sciences and Public Health of Iwate Prefecture: 1-36-1 Iiokashinden, Morioka-shi, Iwate 020-0852, Japan; * Corresponding author

A rapid multiresidue method was developed for determination of 98 veterinary drugs in livestock products and fish by LC/MS/MS. The drugs were extracted with methanol, and the extracted solution was diluted with water. The methanol concentration was adjusted to $50 \%$, and finally the diluted solution was filtered through a microfiltration membrane $(0.02$ $\mu \mathrm{m}$ diameter pore size) prior to LC/MS/MS. Recoveries of 87 drugs from 4 foods (milk, egg, rainbow trout and cattle muscle) fortified at $0.2 \mu \mathrm{g} / \mathrm{g}$ were in the range of $50-150 \%$ with a coefficient of variation $(\%)$ of less than $20 \%$. The values obtained by this method from livestock products containing antibiotics were similar to those obtained by the official methods. This proposed method is expected to be useful as a multiresidue analysis method for screening of veterinary drugs in livestock products and fish.

(Received May 5, 2008)

Key words: 動物用医薬品 veterinary drug; 畜産食品 livestock product; 魚 fish; 一斉分析 simultaneous determination; 高速液体クロマトグラフィー/タンデム質量分析法 LC/MS/MS; 精密ろ過 膜 microfiltration

\section{緒言}

食品中に残留する動物用医薬品は, 食品衛生法に基づく 「食品, 添加物等の規格基準」（昭和 34 年 12 月厚生省告 示第 370 号）によって規制されている. 平成 18 年 5 月 29 日にポジティブリスト制度が施行されたことに伴い, 基準（暫定を含む）が設定された動物用医薬品は 230 項 目以上に大幅に増加し, 抗生物質や抗菌性物質以外の動物 用医薬品のうち基準が設定されていないものについては一 律基準 $(0.01 \mathrm{ppm})$ が適用される。この制度改正に対応す るため, 迅速かつ効率的な動物用医薬品の多成分分析法を 開発し, 食の安全性を確保するため多くの動物用医薬品に ついてモニタリングできる検査体制の強化が求められてい る. 厚生労働省は, 新たに動物用医薬品の試験法として HPLC による一斉試験法 I, II, III および個別試験法*1など を示したが，検出された場合はLC/MSまたはLC/MS/

\section{* 連絡先}

岩手県環境保健研究センター： テ020-0852 岩手県盛岡市 飯岡新田 1-36-1

*1 厚生労働省医薬食品局食品安全部長通知 “食品に残留する 農薬, 飼料添加物又は動物用医薬品の成分である物質の試 験法について”平成 17 年 1 月 24 日, 食安発第 0124001 号 (2005).
MS による確認試験が必要となる. LC/MS/MS は高感 度・高選択性の機能を有するため食品中の夾雑成分の中か ら目的物質を検出する手法として有効であり, 近年, 同機 器による畜水産物中の残留動物用医薬品一斉分析法が多数 報告されている1) 9)

著者らは，限外ろ過法を用いた LC/MS/MSによる農

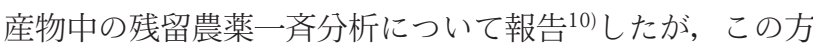
法は, 試料のメ夕ノール抽出液に水を加えて希釈した際に 生成する直径 100～200 nm のコロイド状粒子を限外ろ過 膜により除去し ${ }^{11)}$ ，得られた清澄なろ液を LC/MS/MS で測定するという濃縮操作を省略した迅速分析法である. 本法を畜産物に適用した場合，試料の種類によっては限外 ろ過膜が目詰まりし, 希釈抽出液を全量ろ過できない事例 が見受けられた。 そこで，本報では希釈抽出液中のコロイ ド状粒子を除去する目的で，孔径サイズ $0.02 \mu \mathrm{m}(20 \mathrm{~nm})$ の精密ろ過膜を用いた LC/MS/MSによる動物用医薬品 98 成分を対象とした一斉分析法を検討した。 


\section{実 験 方法}

1. 試料

試料は岩手県内で市販されている牛乳, 鶏卵, 養殖魚 (ニジマス) および牛肉を用いた。 また，抗生物質のベン ジルペニシリン，セファゾリンがそれぞれ検出されたウ シ，ブタの筋肉および腎臓試料を用いた。

\section{2. 試薬および標準品}

溶媒：アセトニトリルおよび蒸留水は LC/MS 用, メ夕 ノールは残留農薬試験用, その他の試薬は特級品で, いず れも関東化学(株)製を用いた。

標準品：関東化学(株)製，林純薬工業(株)製，和光純薬 工業 (株) 製, 肥飼料検査所製, Dr. Ehrenstorfer 社製, LKT Laboratories 社製, MP Biomedicals 社製, Riedelde Haën 社製， Sigma Aldrich 社製，および Toronto Research 社製の標準品を用いた。

標準原液および混合標準溶液：それぞれの溶解性に応じ てアセトニトリル，アセトニトリルー水 $(1: 1)$, ジメチル ホルムアミド, テトラヒドロフラン, メタノールを用いて 溶解し 100〜200 $\mu \mathrm{g} / \mathrm{mL}$ 標準原液を作製した。 なお，キ ノロン系合成抗菌剂は少量の $10 \mathrm{mmol} / \mathrm{L}$ 水酸化ナトリウ ム溶液を用いて溶解し, 蒸留水で定容した。混合標準溶液 は水酸化ナトリウム水溶液に溶解したキノロン系合成抗菌 剂標準品とその他の標準品グループに分けて 50\%メタ ノール溶液で希釈し， 2 種類の混合標準溶液を作製した （各 $1.0 \mu \mathrm{g} / \mathrm{mL}$ の動物用医薬品を含む）。なお，検量線作 成および添加回収試験は 2 種類の混合標準溶液について それぞれ個別に行った。

ろ過膜：精密ろ過膜 Whatman 社製 Anotop ${ }^{\mathrm{TM}} 10$ $(0.02 \mu \mathrm{m})$ (以下 Anotop とする)

\section{3. 装}

高速液体クロマトグラフ：Agilent 社製 1100 シリーズ

質量分析装置：Applied Biosystems 社製 API4000

\section{HPLC 条件}

分析カラム: Waters 社製 Atlantis ${ }^{\mathrm{TM}}$ d-C 18（2.1 mm i.d. $\times 150 \mathrm{~mm}$, 粒子径 $3 \mu \mathrm{m}$ ), 移動相：A 液 0.05\% ギ酸 含有 $10 \mathrm{mmol} / \mathrm{L}$ 酢酸アンモニウム溶液, B 液アセトニト リル，グラジェント条件：ポジティブモード $0 \sim 2$ 分 $(\mathrm{A}$ : $\mathrm{B}=80: 20) \rightarrow 9 \sim 18$ 分 $(\mathrm{A}: \mathrm{B}=10: 90) \rightarrow 18.1 \sim 25$ 分 $(\mathrm{A}:$ $\mathrm{B}=80: 20)$ ，ネガティブモード $0 \sim 2$ 分 $(\mathrm{A}: \mathrm{B}=80: 20) \rightarrow$ $7 \sim 12$ 分 $(\mathrm{A}: \mathrm{B}=10: 90) \rightarrow 12.1 \sim 20$ 分 $(\mathrm{A}: \mathrm{B}=80: 20)$, カラム温度： $40^{\circ} \mathrm{C}$, 流速： $0.2 \mathrm{~mL} / \mathrm{min}$, 注入量： $10 \mu \mathrm{L}$

\section{M S 条 件}

イオン化：エレクトロスプレー (ESI) によるポジティブ ならびにネガティブモード, 分析モード： Multiple Reaction Monitoring (MRM) モード，イオンスプレー電圧: $5.5 \mathrm{kV}$ ならびに一 $4.5 \mathrm{kV}$ ，イオンソース温度： $500^{\circ} \mathrm{C}$

\section{6. 検量線の作成}

キノロン系合成抗菌剤標準品とその他の標準品について それぞれ個別に適宜希釈した混合標準溶液と動物用医薬品 を含有していないことを確認した牛乳，鶏卵，二ジマスお
よび牛肉をおのおの試料調製した試験溶液を $1: 9$ で混合 し， $0.01,0.1,1$ および $10 \mathrm{ng} / \mathrm{mL}$ 濃度のマトリックス添 加標準溶液を調製した。この標準溶液で検量線を作成し, MRM クロマトグラムのピーク面積から濃度を算出した (以下，マトリックス標準添加法).

\section{7. 試験溶液の調製}

魚，牛肉試料はフードプロセッサーを用いペースト状に なるまで磨砕均一化した。 その試料 $5.0 \mathrm{~g}$ を $50 \mathrm{~mL}$ ポリ エチレン遠沈管に採取し，鶏卵，二ジマスおよび牛肉試料 については，水 $2.5 \mathrm{~mL}$ を加え十分に混和し，メタノール $20 \mathrm{~mL}$ 加え，30 分間振とう抽出した後，3,000 rpm で 10 分間遠心分離した。上清を $25 \mathrm{~mL}$ メフラスコに移 し，水を加えて $25 \mathrm{~mL}$ に定容した液 $1 \mathrm{~mL}$ を $10 \mathrm{~mL}$ メス フラスコに分取した。その後，溶液のメタノール濃度を $50 \%$ に調整し，試料の 50 倍希釈液を作製した。得られた 希釈液を Anotop でろ過したろ液を LC/MS/MS 試験溶 液とした。

\section{結果および考察}

\section{L C 条 件}

今回対象とした動物用医薬品は多岐にわたり，さまざま な物理化学的性質を有することから，HPLCカラムは 4 種類のオクタデシルシリル化シリカゲルカラム (Atlantis $^{\mathrm{TM}}$ d-C 18, Cadenza CD-C 18, Mightsil RP-18 GP およびZORBAX Eclipse XDB-C18）についてピーク 形状，力ラム保持，ピーク強度を中心に比較検討した。そ の結果，ペニシリン系抗生物質の保持が優れ，キノロン剂 のピークのテーリングがほとんどなかった Atlantis ${ }^{\mathrm{TM}}$ d-C18 を用いた。

移動相に添加する揮発性の添加剂について，ギ酸 (0.05\%)，酢酸アンモニウム $(10 \mathrm{mmol} / \mathrm{L})$ およびギ酸 $(0.05 \%)+$ 酰酸アンモニウム $(10 \mathrm{mmol} / \mathrm{L})$ を検討したとこ ろ，ギ酸十酢酸アンモニゥムにおいて保持時間が早い動物 用医薬品のピーク形状が良好であったことから $0.05 \%$ ギ 酸含有 $10 \mathrm{mmol} / \mathrm{L}$ 酢酸アンモニゥム溶液を採用した。

有機溶媒はアセトニトリルとメタノールを検討したが, アセトニトリルにおいてマクロライド系抗生物質の繰り返 し再現性が良好であったため，アセトニトリルを採用し た.

\section{M S 条件}

各標準原液をアセトニトリルー水 $(1: 1)$ で希釈し，Q1 スキャンを行い観測される $\left.[\mathrm{M}+\mathrm{H}]^{+}, 〔 \mathrm{M}+2 \mathrm{H}\right]^{2+}, 〔 \mathrm{M}$ 一 H) な などをプリカーサーイオンとして FIA (Flow Injection Analysis)によって，MS/MSのパラメーターを 最適化した。物質の選択性を上げるため, 最も感度が強く 得られたプロダクトイオンを定量用イオンとし，次いで感 度が良かったプロダクトイオンを確認用イオンとする 2 つの MRM トランジションの測定条件をメベンダゾール およびトリフェナム酸以外の 96 成分について設定した。 なお，ペニシリン系やセファロスポリン系抗生物質は両 
Table 1. Compound-specific MS/MS parameters

\begin{tabular}{|c|c|c|c|c|c|c|c|c|c|c|c|}
\hline \multirow[b]{2}{*}{ No. } & \multirow[b]{2}{*}{ Veterinary drugs } & \multirow[b]{2}{*}{$\begin{array}{c}\text { R. T. } \\
(\min )^{a)}\end{array}$} & \multicolumn{4}{|c|}{ Quantitation } & \multicolumn{4}{|c|}{ Confirmation } & \multirow[b]{2}{*}{$\begin{array}{c}\text { LOQ } \\
(\mu \mathrm{g} / \mathrm{g})^{b}\end{array}$} \\
\hline & & & $\begin{array}{c}\text { MRM } \\
\text { transition } \\
(m / z)\end{array}$ & $\begin{array}{l}\text { Declustering } \\
\text { potential } \\
\text { (V) }\end{array}$ & $\begin{array}{c}\text { Collision } \\
\text { energy } \\
\text { (V) }\end{array}$ & $\begin{array}{l}\text { Collision exit } \\
\text { potential } \\
\text { (V) }\end{array}$ & $\begin{array}{c}\text { MRM } \\
\text { transition } \\
(m / z)\end{array}$ & $\begin{array}{l}\text { Declustering } \\
\text { potential } \\
\text { (V) }\end{array}$ & $\begin{array}{c}\text { Collision } \\
\text { energy } \\
\text { (V) }\end{array}$ & $\begin{array}{l}\text { Collision exit } \\
\text { potential } \\
\text { (V) }\end{array}$ & \\
\hline \multicolumn{12}{|c|}{ Positive mode } \\
\hline 1 & Amprolium & 3.3 & $243 \rightarrow 150$ & 26 & 13 & 20 & $243 \rightarrow 94$ & 26 & 15 & 12 & 0.001 \\
\hline 2 & Cefalexin & 3.3 & $348 \rightarrow 158$ & 46 & 13 & 10 & $348 \rightarrow 174$ & 46 & 21 & 10 & 0.01 \\
\hline 3 & Cefapirin & 3.3 & $424 \rightarrow 292$ & 46 & 21 & 16 & $424 \rightarrow 152$ & 46 & 33 & 10 & 0.01 \\
\hline 4 & Ampicillin & 3.4 & $350 \rightarrow 106$ & 56 & 27 & 8 & $350 \rightarrow 160$ & 56 & 17 & 10 & 0.001 \\
\hline 5 & Lincomycin & 4.2 & $407 \rightarrow 126$ & 61 & 39 & 10 & $407 \rightarrow 359$ & 61 & 25 & 10 & 0.001 \\
\hline 6 & Clopidol & 4.4 & $192 \rightarrow 101$ & 76 & 39 & 6 & $192 \rightarrow 87$ & 76 & 43 & 6 & 0.01 \\
\hline 7 & Cefazolin & 4.5 & $455 \rightarrow 323$ & 46 & 15 & 20 & $455 \rightarrow 156$ & 46 & 23 & 8 & 0.01 \\
\hline 8 & Procaine & 4.7 & $237 \rightarrow 100$ & 46 & 23 & 6 & $237 \rightarrow 120$ & 46 & 29 & 20 & 0.001 \\
\hline 9 & Sulfacetamide & 5.2 & $215 \rightarrow 156$ & 51 & 15 & 10 & $215 \rightarrow 92$ & 51 & 31 & 6 & 0.01 \\
\hline 10 & 5-Hydroxythiabendazole & 5.8 & $218 \rightarrow 191$ & 71 & 35 & 14 & $218 \rightarrow 147$ & 71 & 47 & 10 & 0.001 \\
\hline 11 & $\begin{array}{l}\text { 5-Propylsulfonyl- } 1 \mathrm{H} \text { - } \\
\text { benzimidazole-2-amine }\end{array}$ & 5.9 & $240 \rightarrow 133$ & 61 & 39 & 8 & $240 \rightarrow 198$ & 61 & 27 & 4 & 0.001 \\
\hline 12 & Sulfadiazine & 6.0 & $251 \rightarrow 156$ & 46 & 23 & 10 & $251 \rightarrow 92$ & 46 & 39 & 16 & 0.001 \\
\hline 13 & Levamisole & 6.2 & $205 \rightarrow 178$ & 66 & 31 & 32 & $205 \rightarrow 91$ & 66 & 63 & 14 & 0.01 \\
\hline 14 & Sulfathiazole & 6.4 & $256 \rightarrow 156$ & 46 & 21 & 12 & $256 \rightarrow 92$ & 46 & 35 & 16 & 0.001 \\
\hline 15 & Sulfapyridine & 7.2 & $250 \rightarrow 156$ & 46 & 25 & 26 & $250 \rightarrow 92$ & 46 & 35 & 22 & 0.001 \\
\hline 16 & Trimethoprim & 7.5 & $291 \rightarrow 230$ & 61 & 33 & 12 & $291 \rightarrow 261$ & 61 & 35 & 20 & 0.001 \\
\hline 17 & Sulfamerazine & 8.1 & $265 \rightarrow 156$ & 46 & 25 & 8 & $265 \rightarrow 92$ & 46 & 39 & 6 & 0.001 \\
\hline 18 & Ormethoprim & 9.5 & $275 \rightarrow 123$ & 71 & 33 & 8 & $275 \rightarrow 259$ & 71 & 35 & 18 & 0.001 \\
\hline 19 & Pyrantel & 9.6 & $207 \rightarrow 150$ & 71 & 39 & 10 & $207 \rightarrow 136$ & 71 & 43 & 8 & 0.01 \\
\hline 20 & Cefoperazone & 10.3 & $646 \rightarrow 530$ & 71 & 15 & 14 & $646 \rightarrow 143$ & 71 & 47 & 10 & 0.01 \\
\hline 21 & Sulfadimidine & 10.3 & $279 \rightarrow 186$ & 46 & 25 & 10 & $279 \rightarrow 92$ & 46 & 45 & 6 & 0.001 \\
\hline 22 & Sulfamethoxypyridazine & 10.5 & $281 \rightarrow 156$ & 51 & 25 & 12 & $281 \rightarrow 92$ & 51 & 43 & 14 & 0.001 \\
\hline 23 & Morantel & 10.6 & $221 \rightarrow 123$ & 51 & 47 & 8 & $221 \rightarrow 111$ & 51 & 35 & 8 & 0.01 \\
\hline 24 & Neospiramycin & 10.6 & $699 \rightarrow 174$ & 81 & 39 & 10 & $699 \rightarrow 540$ & 81 & 27 & 14 & 0.01 \\
\hline 25 & Ceftiofur & 10.7 & $524 \rightarrow 241$ & 51 & 25 & 14 & $524 \rightarrow 125$ & 51 & 79 & 8 & 0.01 \\
\hline 26 & Spiramycin & 10.7 & $422 \rightarrow 174$ & 60 & 25 & 12 & $422 \rightarrow 101$ & 60 & 69 & 16 & 0.01 \\
\hline 27 & Xylazine & 10.7 & $221 \rightarrow 90$ & 66 & 31 & 6 & $221 \rightarrow 164$ & 66 & 35 & 10 & 0.001 \\
\hline 28 & Benzylpenicillin & 10.8 & $335 \rightarrow 160$ & 61 & 15 & 10 & $335 \rightarrow 176$ & 61 & 17 & 10 & 0.001 \\
\hline 29 & Sulfamonomethoxine & 10.8 & $281 \rightarrow 156$ & 61 & 25 & 12 & $281 \rightarrow 92$ & 61 & 43 & 6 & 0.001 \\
\hline 30 & Thiabendazole & 10.9 & $202 \rightarrow 175$ & 76 & 35 & 10 & $202 \rightarrow 131$ & 76 & 47 & 8 & 0.001 \\
\hline 31 & Phenoxymethylpenicillin & 11.0 & $351 \rightarrow 160$ & 66 & 17 & 28 & $351 \rightarrow 114$ & 66 & 47 & 20 & 0.01 \\
\hline 32 & Pyrimethamine & 11.0 & $249 \rightarrow 177$ & 81 & 41 & 14 & $249 \rightarrow 233$ & 81 & 39 & 12 & 0.001 \\
\hline 33 & Sulfachlorpyridazine & 11.0 & $285 \rightarrow 156$ & 56 & 21 & 12 & $285 \rightarrow 92$ & 56 & 39 & 6 & 0.001 \\
\hline 34 & Oleandomycin & 11.1 & $688 \rightarrow 545$ & 41 & 23 & 14 & $688 \rightarrow 158$ & 41 & 37 & 26 & 0.001 \\
\hline 35 & Oxacillin & 11.1 & $424 \rightarrow 265$ & 51 & 21 & 14 & $424 \rightarrow 182$ & 51 & 23 & 12 & 0.01 \\
\hline 36 & Oxfendazole & 11.1 & $316 \rightarrow 159$ & 66 & 43 & 8 & $316 \rightarrow 191$ & 66 & 29 & 12 & 0.001 \\
\hline 37 & Sulfadoxine & 11.1 & $311 \rightarrow 156$ & 66 & 25 & 12 & $311 \rightarrow 92$ & 66 & 43 & 6 & 0.001 \\
\hline 38 & Sulfamethoxazole & 11.1 & $254 \rightarrow 156$ & 61 & 21 & 14 & $254 \rightarrow 92$ & 61 & 35 & 6 & 0.001 \\
\hline 39 & Cloxacillin & 11.2 & $436 \rightarrow 277$ & 66 & 19 & 8 & $436 \rightarrow 160$ & 66 & 19 & 10 & 0.01 \\
\hline 40 & Erythromycin & 11.2 & $735 \rightarrow 158$ & 96 & 41 & 10 & $735 \rightarrow 577$ & 96 & 25 & 16 & 0.001 \\
\hline 41 & Prednisolone & 11.3 & $361 \rightarrow 343$ & 36 & 15 & 10 & $361 \rightarrow 147$ & 36 & 33 & 10 & 0.001 \\
\hline 42 & Sulfabenzamide & 11.3 & $277 \rightarrow 156$ & 51 & 19 & 12 & $277 \rightarrow 92$ & 51 & 41 & 4 & 0.001 \\
\hline 43 & Sulfisoxazole & 11.3 & $268 \rightarrow 156$ & 61 & 19 & 8 & $268 \rightarrow 92$ & 61 & 21 & 8 & 0.001 \\
\hline 44 & Tripelennamine & 11.3 & $256 \rightarrow 211$ & 36 & 19 & 4 & $256 \rightarrow 91$ & 36 & 47 & 6 & 0.001 \\
\hline 45 & Tylosin & 11.3 & $917 \rightarrow 174$ & 116 & 53 & 10 & $917 \rightarrow 83$ & 116 & 111 & 14 & 0.01 \\
\hline 46 & Ethopabate & 11.4 & $238 \rightarrow 206$ & 46 & 15 & 12 & $238 \rightarrow 136$ & 46 & 31 & 8 & 0.001 \\
\hline 47 & Hydrocortisone & 11.4 & $363 \rightarrow 121$ & 66 & 33 & 8 & $363 \rightarrow 327$ & 66 & 23 & 8 & 0.001 \\
\hline 48 & Nafcillin & 11.4 & $415 \rightarrow 199$ & 61 & 19 & 12 & $415 \rightarrow 171$ & 61 & 51 & 10 & 0.001 \\
\hline 49 & Norfloxacin & 11.4 & $320 \rightarrow 276$ & 51 & 25 & 16 & $320 \rightarrow 233$ & 51 & 33 & 18 & 0.01 \\
\hline 50 & Ofloxacin & 11.4 & $362 \rightarrow 318$ & 76 & 27 & 8 & $362 \rightarrow 261$ & 76 & 37 & 14 & 0.01 \\
\hline 51 & Danofloxacin & 11.5 & $358 \rightarrow 340$ & 61 & 15 & 10 & $358 \rightarrow 257$ & 61 & 19 & 14 & 0.01 \\
\hline 52 & Dicloxacillin & 11.5 & $470 \rightarrow 160$ & 66 & 21 & 10 & $470 \rightarrow 311$ & 66 & 19 & 8 & 0.01 \\
\hline 53 & Enrofloxacin & 11.5 & $360 \rightarrow 316$ & 71 & 27 & 8 & $360 \rightarrow 245$ & 71 & 37 & 14 & 0.01 \\
\hline 54 & Sulfadimethoxine & 11.5 & $311 \rightarrow 156$ & 66 & 31 & 10 & $311 \rightarrow 92$ & 66 & 45 & 6 & 0.001 \\
\hline 55 & Sulfaquinoxaline & 11.5 & $301 \rightarrow 156$ & 71 & 23 & 12 & $301 \rightarrow 92$ & 71 & 39 & 6 & 0.001 \\
\hline 56 & Orbifloxacin & 11.6 & $396 \rightarrow 352$ & 61 & 25 & 10 & $396 \rightarrow 295$ & 61 & 33 & 8 & 0.01 \\
\hline 57 & Oxfendazole sulfone & 11.6 & $332 \rightarrow 300$ & 71 & 33 & 18 & $322 \rightarrow 159$ & 71 & 51 & 10 & 0.001 \\
\hline 58 & Dexamethasone & 11.7 & $393 \rightarrow 373$ & 41 & 13 & 10 & $393 \rightarrow 355$ & 41 & 17 & 10 & 0.001 \\
\hline 59 & Kitasamycin & 11.7 & $773 \rightarrow 109$ & 61 & 67 & 6 & $773 \rightarrow 174$ & 61 & 45 & 12 & 0.01 \\
\hline 60 & Promazine & 11.7 & $285 \rightarrow 86$ & 41 & 25 & 6 & $285 \rightarrow 58$ & 41 & 57 & 2 & 0.001 \\
\hline
\end{tabular}


Table 1. Continued

\begin{tabular}{|c|c|c|c|c|c|c|c|c|c|c|c|}
\hline \multirow[b]{2}{*}{ No. } & \multirow[b]{2}{*}{ Veterinary drugs } & \multirow[b]{2}{*}{$\begin{array}{l}\text { R. T. } \\
(\min )^{a)}\end{array}$} & \multicolumn{4}{|c|}{ Quantitation } & \multicolumn{4}{|c|}{ Confirmation } & \multirow[b]{2}{*}{$\begin{array}{c}\mathrm{LOQ} \\
(\mu \mathrm{g} / \mathrm{g})^{b}\end{array}$} \\
\hline & & & $\begin{array}{c}\text { MRM } \\
\text { transition } \\
(m / z)\end{array}$ & $\begin{array}{c}\text { Declustering } \\
\text { potential } \\
\text { (V) }\end{array}$ & $\begin{array}{c}\text { Collision } \\
\text { energy } \\
(\mathrm{V})\end{array}$ & $\begin{array}{c}\text { Collision exit } \\
\text { potential } \\
(\mathrm{V})\end{array}$ & $\begin{array}{c}\text { MRM } \\
\text { transition } \\
(m / z)\end{array}$ & $\begin{array}{c}\text { Declustering } \\
\text { potential } \\
\text { (V) }\end{array}$ & $\begin{array}{c}\text { Collision } \\
\text { energy } \\
(\mathrm{V})\end{array}$ & $\begin{array}{c}\text { Collision exit } \\
\text { potential } \\
\text { (V) }\end{array}$ & \\
\hline 61 & Sarafloxacin & 11.7 & $386 \rightarrow 368$ & 66 & 29 & 10 & $386 \rightarrow 342$ & 66 & 27 & 10 & 0.01 \\
\hline 62 & Thiamulin & 11.7 & $494 \rightarrow 192$ & 61 & 29 & 4 & $494 \rightarrow 119$ & 61 & 55 & 8 & 0.001 \\
\hline 63 & Mebendazole & 11.8 & $296 \rightarrow 264$ & 59 & 29 & 16 & & & & & 0.001 \\
\hline 64 & Oxibendazole & 11.8 & $250 \rightarrow 218$ & 56 & 27 & 12 & $250 \rightarrow 176$ & 56 & 39 & 12 & 0.001 \\
\hline 65 & Flubendazole & 11.9 & $314 \rightarrow 282$ & 86 & 31 & 6 & $314 \rightarrow 123$ & 86 & 49 & 20 & 0.001 \\
\hline 66 & Corticosterone & 12.0 & $347 \rightarrow 91$ & 71 & 85 & 6 & $347 \rightarrow 77$ & 71 & 97 & 4 & 0.001 \\
\hline 67 & Flumequine & 12.0 & $262 \rightarrow 244$ & 46 & 25 & 14 & $262 \rightarrow 202$ & 46 & 45 & 10 & 0.001 \\
\hline 68 & Nalidixic acid & 12.0 & $233 \rightarrow 215$ & 46 & 21 & 12 & $233 \rightarrow 287$ & 46 & 35 & 12 & 0.001 \\
\hline 69 & Tolfenamic acid & 12.0 & $262 \rightarrow 209$ & 41 & 39 & 4 & & & & & 0.001 \\
\hline 70 & Virginiamycin & 12.0 & $526 \rightarrow 508$ & 71 & 19 & 14 & $526 \rightarrow 355$ & 71 & 25 & 10 & 0.001 \\
\hline 71 & Josamycin & 12.1 & $828 \rightarrow 109$ & 86 & 65 & 8 & $828 \rightarrow 174$ & 86 & 47 & 14 & 0.01 \\
\hline 72 & $\beta$-Trenbolone & 12.2 & $271 \rightarrow 253$ & 71 & 29 & 14 & $271 \rightarrow 199$ & 71 & 31 & 10 & 0.001 \\
\hline 73 & Flunixin & 12.3 & $297 \rightarrow 279$ & 61 & 31 & 6 & $297 \rightarrow 264$ & 61 & 47 & 18 & 0.001 \\
\hline 74 & Ketoprofen & 12.3 & $255 \rightarrow 209$ & 51 & 19 & 4 & $255 \rightarrow 105$ & 51 & 31 & 7 & 0.001 \\
\hline 75 & Oxolinic acid & 12.3 & $262 \rightarrow 216$ & 46 & 41 & 18 & $262 \rightarrow 244$ & 46 & 25 & 6 & 0.001 \\
\hline 76 & Sedecamycin & 12.3 & $301 \rightarrow 156$ & 46 & 17 & 10 & $301 \rightarrow 92$ & 46 & 77 & 14 & 0.01 \\
\hline 77 & Triflupromazine & 12.3 & $353 \rightarrow 58$ & 56 & 69 & 10 & $353 \rightarrow 86$ & 56 & 37 & 14 & 0.001 \\
\hline 78 & $\begin{array}{l}\text { 5-Chloro-6-(2,3-dichlorophenoxy)- } \\
\text { benzimidazole-2-one }\end{array}$ & 12.7 & $329 \rightarrow 168$ & 86 & 41 & 8 & $329 \rightarrow 105$ & 86 & 65 & 6 & 0.01 \\
\hline 79 & Fenbendazole & 12.6 & $300 \rightarrow 268$ & 46 & 29 & 14 & $300 \rightarrow 159$ & 46 & 45 & 26 & 0.001 \\
\hline 80 & Famphur & 12.8 & $326 \rightarrow 281$ & 56 & 21 & 16 & $326 \rightarrow 217$ & 56 & 27 & 12 & 0.01 \\
\hline 81 & Rifaximin & 12.8 & $786 \rightarrow 754$ & 71 & 31 & 22 & $786 \rightarrow 95$ & 71 & 89 & 6 & 0.001 \\
\hline 82 & Novobiocin & 13.2 & $613 \rightarrow 189$ & 56 & 41 & 10 & $613 \rightarrow 218$ & 56 & 19 & 12 & 0.001 \\
\hline 83 & Febantel & 13.4 & $447 \rightarrow 383$ & 66 & 27 & 10 & $447 \rightarrow 415$ & 66 & 19 & 12 & 0.001 \\
\hline 84 & Triclabendazole & 14.1 & $359 \rightarrow 344$ & 71 & 39 & 10 & $359 \rightarrow 274$ & 71 & 52 & 8 & 0.001 \\
\hline 85 & Chlormadinone acetate & 14.3 & $405 \rightarrow 345$ & 51 & 19 & 10 & $405 \rightarrow 309$ & 51 & 23 & 8 & 0.001 \\
\hline 86 & Melengestrol acetate & 14.5 & $397 \rightarrow 337$ & 76 & 19 & 10 & $397 \rightarrow 279$ & 76 & 27 & 8 & 0.001 \\
\hline 87 & Temephos & 15.7 & $467 \rightarrow 405$ & 76 & 21 & 12 & $467 \rightarrow 419$ & 76 & 27 & 12 & 0.01 \\
\hline 88 & Allethrin & 16.1 & $303 \rightarrow 135$ & 36 & 15 & 8 & $303 \rightarrow 93$ & 36 & 19 & 6 & 0.01 \\
\hline 89 & Lasalocid & 17.7 & $613 \rightarrow 377$ & 91 & 49 & 10 & $613 \rightarrow 578$ & 91 & 45 & 16 & 0.001 \\
\hline \multicolumn{12}{|c|}{ Negative mode } \\
\hline 1 & Cefuroxime & 8.7 & $423 \rightarrow 207$ & -35 & -18 & -3 & $423 \rightarrow 318$ & -35 & -12 & -7 & 0.01 \\
\hline 2 & Thiamphenicol & 8.8 & $354 \rightarrow 185$ & -65 & -28 & -11 & $354 \rightarrow 290$ & -65 & -16 & -7 & 0.01 \\
\hline 3 & Florfenicol & 9.0 & $356 \rightarrow 336$ & -60 & -12 & -9 & $356 \rightarrow 185$ & -60 & -26 & -11 & 0.001 \\
\hline 4 & Clorsulon & 9.2 & $378 \rightarrow 342$ & -60 & -16 & -9 & $378 \rightarrow 142$ & -60 & -40 & -1 & 0.01 \\
\hline 5 & Zeranol & 9.7 & $321 \rightarrow 277$ & -75 & -30 & -7 & $321 \rightarrow 303$ & -75 & -30 & -7 & 0.001 \\
\hline 6 & Nicarbazin & 10.2 & $301 \rightarrow 137$ & -55 & -16 & -1 & $301 \rightarrow 107$ & -55 & -48 & -5 & 0.001 \\
\hline 7 & Diclazuril & 10.4 & $405 \rightarrow 334$ & -60 & -26 & -7 & $405 \rightarrow 42$ & -60 & -24 & -7 & 0.001 \\
\hline 8 & Bithionol & 11.1 & $355 \rightarrow 163$ & -60 & -34 & -11 & $355 \rightarrow 194$ & -60 & -34 & -1 & 0.001 \\
\hline 9 & Closantel & 11.7 & $661 \rightarrow 127$ & -70 & -70 & -7 & $661 \rightarrow 345$ & -70 & -50 & -5 & 0.01 \\
\hline
\end{tabular}

a) Retention time

${ }^{b)}$ Limit of quantification $(S / N \geqq 10)$

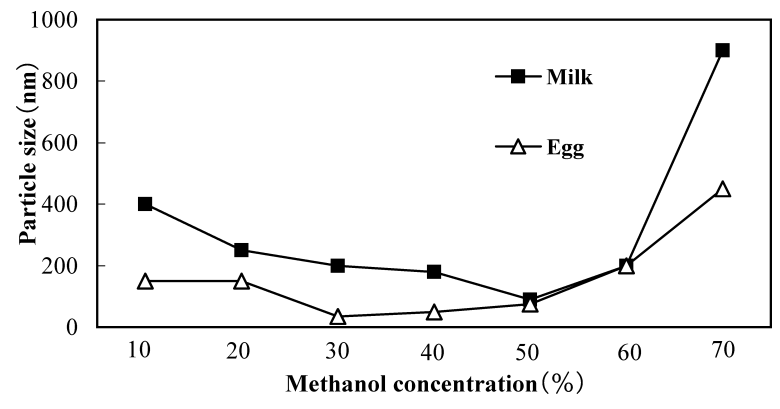

Fig. 1. Distribution of particle size according to methanol concentration in 50-fold dilution of the extracted samples
モードでイオンが確認され，セフロキシム以外はポジティ ブモードの感度が良好であった。 この結果, ポジティブ モードで 89 成分, ネガティブモードで 9 成分の一斉分析 が可能であった. 各物質の MS/MS パラメーターと定量 下限值 $(S / N \geqq 10)$ を Table 1 に示した。定量下限值は $0.001 \sim 0.01 \mu \mathrm{g} / \mathrm{g}$ の範囲で, プレドニゾロンとデキサメ タゾンを除く 96 成分については，検討した全試料におい て基準值レベルの分析に対し十分な感度を有していた。試 料別に見ると，プレドニゾロンは牛肉については適用可能 であった。デキサメタゾンの場合，鶏卵およびニジマスで は不検出とされており, 検出限界值として示されている值 $(0.00005 \mu \mathrm{g} / \mathrm{g})$ を確保できなかったため本法を適用でき なかったが，牛乳および牛肉については適用可能であっ た. 


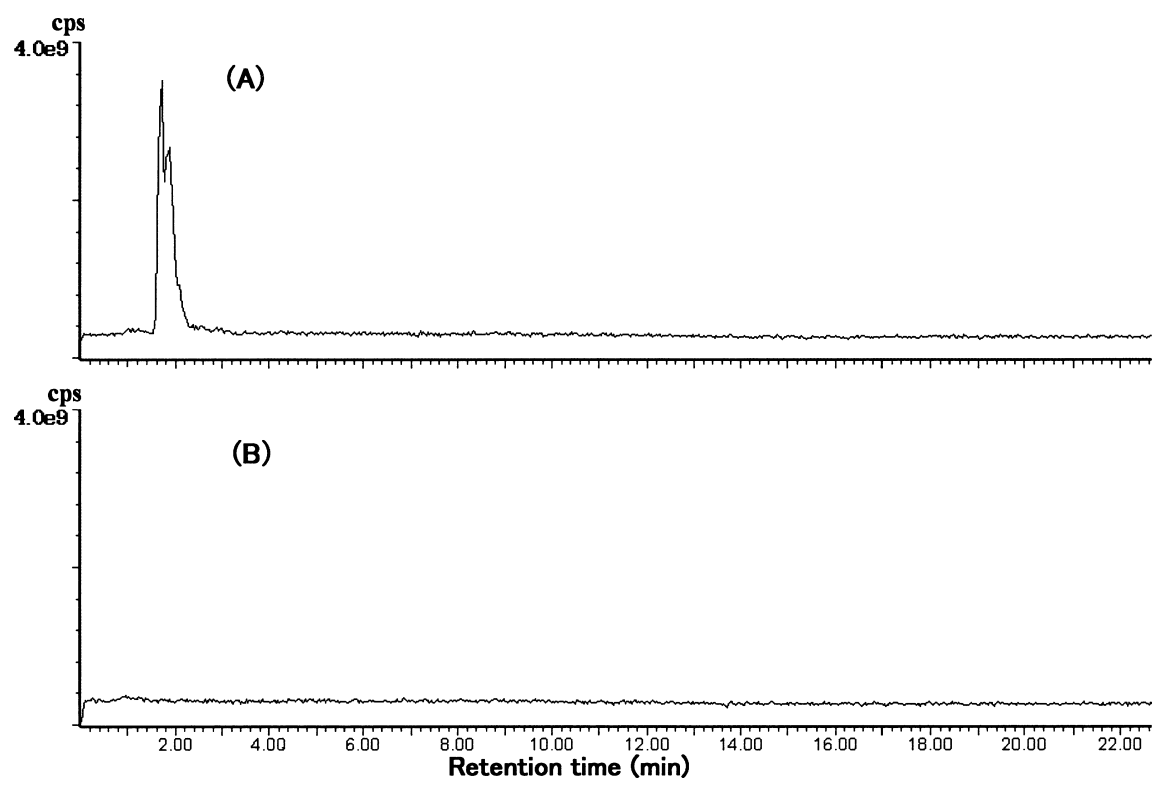

Fig. 2. LC/MS chromatograms of the extracted solution of milk filtered by Anotop (TIC, $m / z=300-400)($ A) $0.2 \mu \mathrm{m}$ diameter pores, (B) $0.02 \mu \mathrm{m}$ diameter pores

MS conditions:

Ionization mode: positive ion electron spray, source block temp.: $100^{\circ} \mathrm{C}$, desolvation temp.: $350^{\circ} \mathrm{C}$, Gas: nitrogen, flow rate: $350 \mathrm{~L} / \mathrm{hr}$, capillary voltage: $3.5 \mathrm{eV}$, cone voltage: $30 \mathrm{~V}$

\section{3. 精密ろ過膜の検討}

牛乳, 鶏卵試料の 50 倍希釈液について粒度分布測定器 （Malvern 社製，Zetasizer Nano-ZS）を用いて粒子径を 測定した結果をFig. 1 に示した。粒子径はメタノール濃 度によって変化し，メタノール濃度を $50 \%$ に調整した場 合，100 200 nm の粒子径に正規分布し，農作物におい ても同じ挙動が観察されている ${ }^{11)}$. 粒子径はメ夕ノール濃 度や希釈倍率による影響を受け，溶液中の粒子径が大きく なると目詰まりを生じやすくなる。また，試料が畜水産物 の場合, 農産物に比べ限外ろ過膜では目詰まりを起こし全 量ろ過できない事例が見受けられた。

精密ろ過膜は分析サンプルの前処理に用いられることが 多く, 孔径 $0.1 \sim 0.45 \mu \mathrm{m}$ のシリンジフィルタータイプが 汎用される. Anotop は 0.02, 0.1 および $0.2 \mu \mathrm{m}$ のイズ があり, 蜂の巣状の微細孔を持つ対称構造の膜である. 今 回検討した $0.02 \mu \mathrm{m}$ の Anotop は, 孔径を考慮すると, 希釈液中に生成したコロイド状粒子は排除されていると推 測される。

牛乳試料に $0.2 \mu \mathrm{g} / \mathrm{g}$ 相当の混合標準液を添加した 50 倍希釈液を限外 過膜 ULTRAFREE-MC 30000 (Millipore 社製) とAnotopでそれぞれ処理し，万過膜 の比較を行ったところ，回収率 70〜120\%かっ CV 20\% 以下の薬剤は限外万過膜で 88 成分, Anotop で 94 成分 とAnotopのほうが多くの薬剤に適用できた.この原因 として, 検討した二つのろ過膜は膜の素材, 構造などが異 なることから動物用医薬品の膜への吸着性の違いが考えら れた。

精製効果を確認するため，牛乳試料を用いて 0.2 および $0.02 \mu \mathrm{m}$ サイズの Anotop でろ過した試験溶液を LC/MS
でトータルイオンクロマトグラム (TIC) を測定した。装置 は日本ウォーターズ(株)製 Alliance LC/MS システム (HPLC: Alliance2690, MS: ZMD4000) を用い, HPLC 条 件は実験方法 4 の条件で行なった。 $m / z 100$ から $m / z$ 600 の範囲で 100 ずっ区切って TIC を測定したところ, $\mathrm{m} / \mathrm{z}=300 \sim 400, \mathrm{~m} / \mathrm{z}=400 \sim 500, \mathrm{~m} / \mathrm{z}=500 \sim 600$ のク ロマトグラムにおいて $0.02 \mu \mathrm{m}$ サイズの Anotop の精製 効果が確認された. Fig. 2 に $m / z=300 \sim 400$ のクロマト グラムを示したが，妨害ピークが除去され，良好なクロマ トグラムが得られた。

\section{4. マトリックスによるイオン化への影響}

LC/MS/MS による測定は試料中の夾雑成分の影響を受 け，イオン化抑制や促進効果いわゆるマトリックス効果を 受けることが知られている1) 5). このマトリックス効果を 補正する方法として安定同位体等による内部標準添加法が 推奨されるが1),2),12)，多成分分析の場合，定量対象物質に 対応した内部標準品を選定することは困難である。今回, 対象とした 4 試料についてポジティブモードで測定する 84 化合物について試験溶液に $10 \mathrm{ng} / \mathrm{mL}$ 濃度になるよう に標準溶液を添加してシリンジスパイクを行い，マトリッ クス効果を確認した。牛乳試料の場合, 65 成分が $100 \pm$ $20 \%$ のス゚イク回収率が得られ，50\%以下は 2 成分で あった。なお，同じ成分でも試料の種類によってマトリッ クス効果の程度は異なっていた。 そこで，本試験法では定 量の精度を高めるため, マトリックス標準添加法を用い た.

\section{5. 添加回収試験}

あらかじめ動物用医薬品が含有していないことを確認し た 4 種類の試料に混合標準溶液を $0.2 \mu \mathrm{g} / \mathrm{g}$ となるように 
Table 2. Recoveries of veterinary drugs added to livestock products and fish

\begin{tabular}{|c|c|c|c|c|c|c|c|c|c|}
\hline \multirow{3}{*}{ No. } & \multirow{3}{*}{ Veterinary drugs } & \multicolumn{8}{|c|}{ Recovery $(\%)^{a)}$} \\
\hline & & \multicolumn{2}{|c|}{ Milk } & \multicolumn{2}{|c|}{ Egg } & \multicolumn{2}{|c|}{ Rainbow trout } & \multicolumn{2}{|c|}{ Cattle muscle } \\
\hline & & Mean & $\mathrm{CV}$ & Mean & $\mathrm{CV}$ & Mean & $\mathrm{CV}$ & Mean & $\mathrm{CV}$ \\
\hline \multicolumn{10}{|c|}{ Positive mode } \\
\hline 1 & Amprolium & 97.5 & 9.4 & 97.8 & 8.8 & 103.8 & 6.5 & 100.0 & 5.1 \\
\hline 2 & Cefalexin & 93.3 & 13.3 & 84.9 & 10.2 & 61.3 & 11.7 & 74.4 & 11.9 \\
\hline 3 & Cefapirin & 115.6 & 4.9 & 89.6 & 1.1 & 89.2 & 15.4 & 76.1 & 7.3 \\
\hline 4 & Ampicillin & 81.8 & 16.5 & 78.0 & 0.3 & 70.3 & 6.3 & 75.6 & 3.9 \\
\hline 5 & Lincomycin & 96.3 & 4.2 & 84.8 & 6.4 & 77.0 & 4.9 & 78.7 & 6.2 \\
\hline 6 & Clopidol & 95.0 & 8.2 & 83.1 & 7.8 & 93.3 & 6.2 & 81.3 & 12.1 \\
\hline 7 & Cefazolin & 110.0 & 1.2 & 99.2 & 8.1 & 79.4 & 5.8 & 64.6 & 4.7 \\
\hline 8 & Procaine & 88.7 & 4.8 & 76.9 & 4.1 & 73.9 & 4.3 & 85.1 & 6.8 \\
\hline 9 & Sufacetamide & 101.6 & 6.9 & 88.9 & 9.6 & 73.8 & 8.1 & 82.7 & 11.8 \\
\hline 10 & 5-Hydroxythiabendazole & 94.9 & 5.6 & 80.6 & 6.0 & 72.7 & 5.1 & 82.5 & 7.1 \\
\hline 11 & 5-Propylsulfonyl-1H-benzimidazole-2-amine & 94.6 & 3.4 & 84.1 & 4.7 & 75.6 & 5.1 & 77.0 & 7.1 \\
\hline 12 & Sulfadiazine & 94.0 & 4.9 & 82.9 & 4.4 & 75.3 & 6.3 & 83.9 & 6.4 \\
\hline 13 & Levamisole & 95.4 & 8.1 & 81.4 & 3.2 & 74.9 & 9.9 & 77.9 & 6.2 \\
\hline 14 & Sulfathiazole & 92.8 & 5.0 & 83.8 & 4.8 & 75.5 & 5.2 & 80.7 & 7.5 \\
\hline 15 & Sulfapyridine & 94.5 & 3.1 & 79.8 & 2.7 & 76.4 & 3.9 & 80.0 & 5.7 \\
\hline 16 & Trimethoprim & 94.0 & 4.9 & 83.0 & 3.2 & 72.3 & 3.3 & 78.7 & 3.7 \\
\hline 17 & Sulfamerazine & 94.1 & 5.3 & 81.2 & 4.1 & 74.8 & 1.5 & 78.6 & 7.4 \\
\hline 18 & Ormethoprim & 81.8 & 2.9 & 90.7 & 9.3 & 71.3 & 3.2 & 74.3 & 13.1 \\
\hline 19 & Pyrantel & 91.8 & 9.6 & 73.0 & 15.1 & 67.0 & 13.1 & 82.0 & 23.4 \\
\hline 20 & Cefoperazone & 107.3 & 6.9 & 87.3 & 5.9 & 88.6 & 5.2 & 75.8 & 6.9 \\
\hline 21 & Sulfadimidine & 90.8 & 9.1 & 89.9 & 7.0 & 76.8 & 5.9 & 84.4 & 8.6 \\
\hline 22 & Sulfamethoxypyridazine & 93.8 & 7.3 & 88.0 & 6.9 & 76.9 & 5.3 & 86.1 & 7.7 \\
\hline 23 & Morantel & 83.3 & 8.3 & 82.8 & 8.6 & 83.3 & 3.1 & 85.9 & 5.5 \\
\hline 24 & Neospiramycin & 69.8 & 11.7 & 65.6 & 5.0 & 70.2 & 3.8 & 80.3 & 5.0 \\
\hline 25 & Ceftiofur & 101.8 & 3.9 & 81.5 & 6.4 & 76.3 & 5.5 & 75.7 & 5.0 \\
\hline 26 & Spiramycin & 91.2 & 3.9 & 81.1 & 0.6 & 83.6 & 6.7 & 75.8 & 11.0 \\
\hline 27 & Xylazine & 86.1 & 7.1 & 77.5 & 6.2 & 72.9 & 4.6 & 80.0 & 8.5 \\
\hline 28 & Benzylpenicillin & 100.7 & 3.4 & 86.4 & 4.6 & 83.9 & 1.8 & 79.6 & 4.9 \\
\hline 29 & Sulfamonomethoxine & 93.8 & 16.3 & 97.0 & 12.0 & 77.8 & 19.2 & 92.4 & 13.3 \\
\hline 30 & Thiabendazole & 86.3 & 5.7 & 85.3 & 8.6 & 76.7 & 7.6 & 78.8 & 10.3 \\
\hline 31 & Phenoxymethylpenicillin & 103.8 & 1.7 & 87.4 & 5.6 & 75.8 & 4.1 & 77.9 & 12.2 \\
\hline 32 & Pyrimethamine & 90.2 & 6.5 & 84.3 & 8.2 & 66.0 & 7.6 & 74.6 & 7.0 \\
\hline 33 & Sulfachlorpyridazine & 109.1 & 12.1 & 96.3 & 12.5 & 69.3 & 20.6 & 81.2 & 10.7 \\
\hline 34 & Oleandomycin & 85.8 & 2.4 & 78.2 & 1.0 & 76.0 & 3.8 & 74.9 & 5.7 \\
\hline 35 & Oxacillin & 103.7 & 10.7 & 116.3 & 11.2 & 104.5 & 8.5 & 83.6 & 7.2 \\
\hline 36 & Oxfendazole & 103.6 & 9.7 & 103.6 & 11.4 & 84.2 & 9.8 & 99.0 & 8.0 \\
\hline 37 & Sulfadoxine & 103.4 & 7.1 & 92.7 & 5.9 & 78.8 & 11.6 & 92.2 & 7.9 \\
\hline 38 & Sulfamethoxazole & 109.6 & 12.8 & 101.9 & 7.5 & 86.8 & 15.1 & 97.8 & 9.6 \\
\hline 39 & Cloxacillin & 99.0 & 7.2 & 104.8 & 6.2 & 82.5 & 3.1 & 71.4 & 6.9 \\
\hline 40 & Erythromycin & 85.8 & 6.3 & 79.8 & 2.1 & 75.7 & 1.5 & 77.7 & 2.6 \\
\hline 41 & Prednisolone & 106.3 & 5.2 & 90.4 & 7.2 & 81.3 & 6.2 & 93.9 & 9.3 \\
\hline 42 & Sulfabenzamide & 106.4 & 6.3 & 92.7 & 9.2 & 74.5 & 6.3 & 83.8 & 7.3 \\
\hline 43 & Sulfisoxazole & 110.4 & 14.9 & 97.9 & 9.4 & 71.7 & 19.2 & 90.6 & 9.2 \\
\hline 44 & Tripelennamine & 89.7 & 3.7 & 79.2 & 4.2 & 77.8 & 6.3 & 82.8 & 9.7 \\
\hline 45 & Tylosin & 72.9 & 20.9 & 71.3 & 4.2 & 74.0 & 10.0 & 72.8 & 3.2 \\
\hline 46 & Ethopabate & 95.0 & 4.3 & 89.1 & 6.6 & 80.4 & 4.7 & 82.5 & 8.7 \\
\hline 47 & Hydrocortisone & 97.0 & 4.5 & 86.8 & 10.9 & 79.2 & 11.7 & 77.1 & 3.8 \\
\hline 48 & Nafcillin & 84.9 & 3.2 & 89.3 & 7.3 & 65.4 & 8.0 & 67.2 & 6.6 \\
\hline 49 & Norfloxacin & 54.7 & 14.4 & 32.9 & 10.7 & 146.3 & 1.6 & 36.3 & 28.7 \\
\hline 50 & Ofloxacin & 82.0 & 12.2 & 71.7 & 7.7 & 141.6 & 2.9 & 32.8 & 19.7 \\
\hline 51 & Danofloxacin & 70.2 & 15.0 & 48.3 & 15.8 & 158.5 & 6.6 & 35.7 & 36.6 \\
\hline 52 & Dicloxacillin & 90.8 & 5.6 & 88.1 & 3.9 & 75.8 & 3.1 & 83.9 & 9.0 \\
\hline 53 & Enrofloxacin & 93.3 & 9.9 & 74.9 & 7.9 & 136.5 & 3.3 & 34.2 & 16.8 \\
\hline 54 & Sulfadimethoxine & 101.4 & 10.7 & 98.6 & 9.9 & 79.0 & 16.5 & 91.0 & 11.7 \\
\hline 55 & Sulfaquinoxaline & 108.2 & 15.6 & 109.9 & 17.4 & 80.7 & 22.3 & 95.2 & 12.9 \\
\hline 56 & Orbifloxacin & 116.6 & 1.0 & 101.3 & 4.3 & 119.3 & 1.4 & 98.8 & 0.8 \\
\hline 57 & Oxfendazole sulfone & 105.4 & 7.8 & 98.3 & 9.3 & 74.1 & 14.8 & 94.3 & 7.4 \\
\hline 58 & Dexamethasone & 105.1 & 9.7 & 100.8 & 12.8 & 77.7 & 9.4 & 89.1 & 10.4 \\
\hline 59 & Kitasamycin & 99.0 & 5.5 & 74.3 & 7.7 & 77.0 & 17.6 & 60.8 & 5.4 \\
\hline 60 & Promazine & 86.0 & 6.0 & 69.3 & 4.7 & 58.0 & 4.0 & 66.8 & 9.1 \\
\hline
\end{tabular}


Table 2. Continued

\begin{tabular}{|c|c|c|c|c|c|c|c|c|c|}
\hline \multirow{3}{*}{ No. } & \multirow{3}{*}{ Veterinary drugs } & \multicolumn{8}{|c|}{ Recovery $(\%)^{a)}$} \\
\hline & & \multicolumn{2}{|c|}{ Milk } & \multicolumn{2}{|c|}{ Egg } & \multicolumn{2}{|c|}{ Rainbow trout } & \multicolumn{2}{|c|}{ Cattle muscle } \\
\hline & & Mean & $\mathrm{CV}$ & Mean & $\mathrm{CV}$ & Mean & $\mathrm{CV}$ & Mean & $\mathrm{CV}$ \\
\hline 61 & Sarafloxacin & 74.5 & 2.1 & 51.1 & 3.6 & 105.3 & 4.4 & 41.0 & 12.8 \\
\hline 62 & Thiamulin & 87.2 & 2.6 & 78.9 & 1.3 & 72.8 & 2.3 & 76.0 & 5.4 \\
\hline 63 & Mebendazole & 107.0 & 13.2 & 98.3 & 13.9 & 81.6 & 6.6 & 90.4 & 11.8 \\
\hline 64 & Oxibendazole & 98.1 & 7.9 & 93.9 & 6.5 & 73.1 & 8.0 & 87.9 & 5.9 \\
\hline 65 & Flubendazole & 104.9 & 5.2 & 101.7 & 10.1 & 73.3 & 17.4 & 90.3 & 8.4 \\
\hline 66 & Corticosterone & 105.3 & 17.5 & 92.1 & 6.8 & 75.3 & 15.0 & 79.0 & 6.8 \\
\hline 67 & Flumequine & 80.8 & 11.0 & 26.6 & 40.2 & 64.3 & 14.3 & 74.7 & 7.0 \\
\hline 68 & Nalidixic acid & 82.1 & 15.7 & 11.5 & 26.1 & 65.7 & 13.2 & 72.6 & 8.6 \\
\hline 69 & Tolfenamic acid & 81.6 & 12.9 & 24.7 & 41.3 & 66.0 & 13.5 & 76.6 & 6.9 \\
\hline 70 & Virginiamycin & 89.6 & 4.3 & 82.2 & 1.0 & 75.4 & 1.1 & 77.8 & 4.0 \\
\hline 71 & Josamycin & 90.9 & 9.2 & 78.9 & 3.3 & 82.2 & 8.9 & 67.0 & 14.2 \\
\hline 72 & $\beta$-Trenbolone & 93.7 & 11.5 & 90.7 & 9.8 & 72.7 & 15.0 & 82.1 & 6.4 \\
\hline 73 & Flunixin & 99.0 & 10.0 & 92.5 & 11.6 & 72.3 & 17.1 & 77.5 & 8.6 \\
\hline 74 & Ketoprofen & 95.8 & 2.6 & 85.2 & 1.4 & 75.6 & 2.3 & 78.0 & 8.6 \\
\hline 75 & Oxolinic acid & 125.0 & 0.8 & 62.8 & 7.6 & 139.8 & 1.9 & 71.0 & 8.6 \\
\hline 76 & Sedecamycin & 103.0 & 6.3 & 98.3 & 6.4 & 82.2 & 10.6 & 78.8 & 7.8 \\
\hline 77 & Triflupromazine & 85.8 & 6.1 & 69.5 & 5.6 & 62.9 & 5.4 & 70.6 & 6.4 \\
\hline 78 & $\begin{array}{l}\text { 5-Chloro-6-(2, 3-dichlorophenoxy)- } \\
\text { benzimidazole-2-one }\end{array}$ & 87.4 & 13.1 & 77.5 & 18.3 & 77.3 & 4.0 & 66.2 & 26.9 \\
\hline 79 & Fenbendazole & 103.1 & 9.1 & 90.1 & 9.9 & 70.3 & 10.2 & 84.8 & 9.4 \\
\hline 80 & Famphur & 90.3 & 3.6 & 88.7 & 6.5 & 75.4 & 1.7 & 87.2 & 15.5 \\
\hline 81 & Rifaximin & 112.6 & 10.9 & 67.9 & 8.4 & 83.5 & 16.3 & 95.5 & 10.5 \\
\hline 82 & Novobiocin & 87.2 & 8.9 & 74.7 & 4.1 & 68.2 & 3.3 & 68.0 & 1.3 \\
\hline 83 & Febantel & 92.8 & 6.3 & 81.3 & 6.2 & 75.3 & 3.3 & 83.3 & 7.9 \\
\hline 84 & Triclabendazole & 114.1 & 14.7 & 68.6 & 5.7 & 65.1 & 4.7 & 76.6 & 8.9 \\
\hline 85 & Chlormadinone acetate & 102.6 & 18.2 & 75.8 & 15.2 & 69.8 & 13.1 & 83.3 & 11.5 \\
\hline 86 & Melengestrol acetate & 99.3 & 13.2 & 79.7 & 5.2 & 72.9 & 10.7 & 80.3 & 7.7 \\
\hline 87 & Temephos & 84.0 & 9.9 & 73.9 & 13.1 & 64.2 & 6.4 & 77.9 & 10.5 \\
\hline 88 & Allethrin & 83.4 & 7.7 & 75.3 & 5.6 & 67.7 & 10.7 & 77.2 & 16.5 \\
\hline 89 & Lasalocid & 152.0 & 11.4 & 111.8 & 16.6 & 85.8 & 13.9 & 96.6 & 7.5 \\
\hline \multicolumn{10}{|c|}{ Negative mode } \\
\hline 1 & Cefuroxime & 75.9 & 8.3 & 84.0 & 11.3 & 91.6 & 7.4 & 61.1 & 7.4 \\
\hline 2 & Thiamphenicol & 89.8 & 3.9 & 81.3 & 2.4 & 92.2 & 1.8 & 76.3 & 3.5 \\
\hline 3 & Florfenicol & 90.3 & 0.8 & 86.0 & 2.3 & 100.8 & 4.9 & 75.5 & 1.3 \\
\hline 4 & Clorsulon & 84.7 & 2.5 & 74.2 & 0.2 & 93.0 & 5.2 & 69.0 & 0.7 \\
\hline 5 & Zeranol & 84.0 & 1.3 & 81.3 & 1.2 & 90.8 & 2.4 & 77.0 & 3.1 \\
\hline 6 & Nicarbazin & 79.8 & 1.4 & 68.0 & 1.3 & 70.5 & 2.5 & 68.8 & 2.4 \\
\hline 7 & Diclazuril & 91.9 & 2.0 & 81.0 & 2.5 & 92.6 & 1.6 & 70.9 & 1.9 \\
\hline 8 & Bithionol & 73.0 & 4.6 & 59.8 & 4.2 & 70.3 & 1.6 & 64.4 & 3.5 \\
\hline 9 & Closantel & 85.4 & 0.9 & 82.1 & 1.2 & 69.7 & 1.5 & 65.8 & 2.0 \\
\hline
\end{tabular}

a) Sample was spiked with $0.2 \mu \mathrm{g} / \mathrm{g}$ of each veterinary drugs $n=3$

Table 3. Comparison between the results of the proposed method and offical methods in livestock products contaminated with veterinary drugs

\begin{tabular}{llcc}
\hline \hline Vetrinary drugs & Sample & $\begin{array}{c}\text { Proposed method } \\
\text { residue }(\mu \mathrm{g} / \mathrm{g})\end{array}$ & $\begin{array}{c}\text { Official method } \\
\text { residue }(\mu \mathrm{g} / \mathrm{g})\end{array}$ \\
\hline Benzylpenicillin & Cattle muscle & 0.003 & 0.002 \\
Benzylpenicillin & Cattle kidney & 0.19 & 0.18 \\
Benzylpenicillin & Pig muscle & 0.06 & 0.05 \\
Benzylpenicillin & Pig kidney & 0.15 & 0.12 \\
Cefazolin & Cattle muscle & 3.9 & 4.2 \\
Cefazolin & Cattle kidney & 17.8 & 23.0 \\
\hline
\end{tabular}


添加したときの回収率を求めた. Table 2 に示したよう に，検討したすべての試料において回収率 70〜120\%か つCV20\%以下であった薬剤は 66 成分で, 試料別では牛 乳 94 , 鶏卵 84 , ニジマス 77 , 牛肉 81 成分と違いが認めら れた。全試料において回収率 50〜 150\%，CV 20\%以下 であった薬剤を本法によるスクリーニング検査が適用可能 と考えた場合，98 成分中 87 成分が分析可能であった。 また，鶏卵および牛肉試料ではフルオロキノロン剂の回収 率が 50\%未満の低回収率を示すものがあった。この原因 としてろ過膜への吸着 ${ }^{13)}$ や抽出が不十分なことが考えられ た。キノロン剂の抽出溶媒としてギ酸6)やメタリン酸 ${ }^{14)}$ アセトニトリルに添加し酸性下で抽出する方法が報告され ており，今回用いたメタノールでは試料の種類によっては 十分抽出されないことが考えられ, 本法を適用することは 困難と考えられた。

\section{6. 公定検査法との比較}

ベンジルペニシリン，セファゾリンが残留するウシ，ブ 夕の筋肉および腎臓試料を用いて本法と公定検査法*1によ る分析值を比較し, Table 3 に示した. 公定検査法*1のべ ンジルペニシリン試験法によって得られた試験溶液を LC/MS/MSにて測定した分析值と, 本法の分析值とはほ ぼ一致した。セファゾリンの場合, 本法では筋肉 $3.9 \mu \mathrm{g} /$ $\mathrm{g}$, 腎臓 $17.8 \mu \mathrm{g} / \mathrm{g}$ に対し, 公定検査法*1ではそれぞれ 4.2 $\mu \mathrm{g} / \mathrm{g}, 23 \mu \mathrm{g} / \mathrm{g}$ と高めの值であった. この原因として, 公 定検査法*1で得られた試験溶液については 80 倍に希釈し 測定したため, 希釈倍率の違いが影響したものと考えられ た。

ペンジルペニシリンについて定量用イオンに対する確認 用イオンの比を標準品, マトリックス添加標準品および実 試料ごとに比較した。標準品の 0.94 に対し，マトリック ス標準品とウシ，ブタの筋肉および腎臓試料では 0.91〜 0.96 の範囲でイオン比はほぼ一致していた.

\section{8. 実態調 査}

本法を用いて市販の鶏卵 20 検体について, 試験法とし ての妥当性を確認した 84 成分を対象に残留実態調査を実 施したところ, いずれの検体からも動物用医薬品は検出さ れなかった。

\section{ま と め}

畜水産物中の残留動物用医薬品 98 成分について LC/ MS/MS による一斉分析法を検討した。

1. 前処理法はメ夕ノールで抽出後, 水を加え, メ夕 ノール濃度 50\%に調整した試料の 50 倍希釈液を 孔径 $0.02 \mu \mathrm{m}$ の精密ろ過膜 Anotop で精製した.

2. 定量下限值は $0.001 \sim 0.01 \mu \mathrm{g} / \mathrm{g}$ の範囲で, プレド ニゾロンとデキサメタゾンを除く 96 成分について 基準值レベルの分析が可能であった。

3. $0.2 \mu \mathrm{g} / \mathrm{g}$ 濃度の添加回収試験で回収率 $70 \sim 120 \%$ の回収率が得られたのは 66 成分，50～150\%の回 収率が得られたのは 87 成分であった。
4. 抗生物質が検出された試料を用いて, 本法と公定検 査法を比較したところ，值はほぼ一致し，十分な真 度で分析可能であった。

5. 本法を適用して, 市販の鶏卵 20 検体について残留 実態調査を行ったところ，いずれの検体からも動物 用医薬品は検出されなかった。

6. 本法は固相抽出処理, 濃縮操作を省略でき, 迅速か つ簡易に物性の異なる多くの薬剤について一斉分析 可能なことから，畜水産物中の残留動物用医薬品ス クリーニング法として有用であると考える.

\section{謝 辞}

本研究を実施するに当たり，試料を提供していただいた 岩手県食肉衛生検査所関係各位に深謝いたします。

\section{文献}

1) Riediker, S., Stadler, R. H. Simultaneous determination of five $\beta$-lactam antibiotics in bovine milk using liquid chromatography coupled with electrospray ionization tandem mass spectrometry. Anal. Chem., 73, 1614-1621 (2001).

2) Hatano, K. Simultaneous determination of five penicillins in muscle, liver and kidney from slaughtered animals using liquid chromatography coupled with elctrospray ionization tandem mass spectrometry. Shokuhin Eiseigaku Zasshi (J. Food Hyg. Soc. Japan), 44, 1-6 (2003).

3) Yamada, R., Kozono, M., Ohmori, T., Kato, M., Morimatsu, F., Kitayama, M. Multi-residue analysis of residual veterinary drugs in muscle using liquid chromatography coupled with electrospray ionization tandem mass spectrometry. Seikatsu Eisei (Journal of Urban Living and Health Association), 49, 152-160 (2005).

4) Hashimoto, T., Kaji, M., Namikawa, M., Komeda, M., Niimi, T., Yoshii, K., Morita, K., Kawakami, M., Tsuji, Y., Kawakatsu, T. Simultaneous determination of residual animal drugs in livestock products and seafoods by LC / MS / MS. Kyotoshi Eiseikougai Kenkyusho Nenpo (Annual Report of Kyoto City Institute of Health and Environmental Sciences), 76, 122-130, (2006).

5) Ishii, R., Horie, M., Murayama, M., Maitani, T. Analysis of tetracyclines in honey and royal jelly by LC/MS/ MS. Shokuhin Eiseigaku Zasshi (J. Food Hyg. Soc. Japan), 47, 277-283 (2006).

6) Hatano, K. Simultaneous determination of quinolones in foods by LC/MS/MS. Shokuhin Eiseigaku Zasshi (J. Food Hyg. Soc. Japan), 45, 239-244 (2004).

7) Kai, S., Akaboshi, T., Kishi, M., Kanazawa, H., Kobayashi, S. Analysis of benzimidazole anthelmintics in livestock foods by HPLC / MS / MS. BUNSEKI KAGAKU, 54, 775-782 (2005).

8) Yamada, R., Kozono, M., Ohmori, T., Morimatsu, F., Kitayama, M. Simultaneous determination of residual veterinary drugs in bovine, porcine, and chicken 
muscle using liquid chromatography coupled with electrospray ionization tandem mass spectrometry. Biosci. Biotechnol. Biochem., 70, 54-65 (2006).

9) Tagiri-Endo, M., Yanagita, N. Simultaneous determination of residual veterinary drugs in muscle by on-line solid phase extraction/high-performance liquid chromatography/tandem mass spectrometry. BUNSEKI KAGAKU, 56, 317-326 (2007).

10) Hatakeyama, E., Kajita, H., Sugawara, T., Sasaki, A., Takahashi, S., Komukai, T. Simultaneous determination of pesticides in agricultural products by LC/MS/ MS using clean-up with ultrafiltration. Shokuhin Eiseigaku Zasshi (J. Food Hyg. Soc. Japan), 47, 137145 (2006).
11) Kajita, H. Practical use and technical notice of ultrafiltration membrane for analysis of pesticide residues and veterinary drugs in foods. Shokuhin Eiseigaku Zasshi (J. Food Hyg. Soc. Japan), 48, J5-6 (2007).

12）（社）日本分析化学会液体クロマトグラフィー研究懇談会編 集. “液ク口彪の巻”，茨城，筑波出版会，2003，p. 136137.

13) 長浜邦雄監修. 普及版高純度化技術大系 “第 2 巻分離技 術”，東京，フジテクノシステム，2001, p. 605-656.

14) Horie, M., Saito, K., Hoshino, Y., Terada, H., Nakazawa, H. Simultaneous determination of enrofloxacin and its primary metabolite ciprofloxacin in meat and fish by HPLC. Shokuhin Eiseigaku Zasshi (J. Food Hyg. Soc. Japan), 38, 329-334 (1997). 